\title{
Evaluating work and training within an intercommunicating process of change: reflections drawn from a case study on a chemicals industrial company in Portugal
}

\author{
Ricardo Vasconcelos ${ }^{\mathrm{a},}{ }^{*}$, Daniel Silva ${ }^{\mathrm{b}}$, Ricardo Pinto ${ }^{\mathrm{b}}$ and Sérgio Duarte ${ }^{\mathrm{a}}$ \\ ${ }^{\mathrm{a}}$ Centro de Psicologia da Universidade do Porto, Faculdade de Psicologia e de Ciências da Educação- \\ Universidade do Porto, Rua do Dr. Manuel Pereira da Silva, 4200-392, Porto, Portugal \\ ${ }^{\mathrm{b}}$ Serviço de Consultadoria em Psicologia do Trabalho, Faculdade de Psicologia e de Ciências da Educação- \\ Universidade do Porto, Rua do Dr. Manuel Pereira da Silva, 4200-392, Porto, Portugal
}

\begin{abstract}
The new challenges in the field of Health and Safety at Work require the implementation of more comprehensive and participatory interventions, in order to have a real impact on the working conditions. Matriosca Model has sought over the years to involve workers in the construction of new working conditions, promoting transformation through training and recreating training from the transformation. This article seeks to present some of the results of the implementation of the Matriosca Model on a chemicals industrial company regarding the many changes that it promoted, how these changes have evolved through time, how the dimensions of training and transformation interact and what the participants' perception of the intervention was. The conclusions drawn allow a richer evaluation of the process, which can enhance the intercommunicating nature between training and transformation, and what impact this has on the actual work.
\end{abstract}

Keywords: Matriosca, hands-on-training, evaluation, safety promotion, work transformation

\section{Introduction}

\subsection{Prevention in Health and Safety at Work today}

In 1989 the Framework Directive 89/391/EC formalized a set of guidelines and prescriptions regarding the prevention and promotion of Health and Safety at Work (HSW), that reflected the emerging concerns about this issue. However, the practical application of the provisions listed in the directive seems to contradict its truly preventive, integrated and participatory philosophy $[1,4]$. In many professional contexts, HSW related issues tend to reflect a formal and procedural perspective of prevention, which, through the strict application of the prescriptions, results in a "legalistic behavior" by companies [14]. Strictly speaking, companies seem convinced that the compliance with the requirements by the workers is sufficient to ensure their safety and health, as they perceive the work systems as predefined, stable and possible to determine a priori [6].

They forget, however, that the renewal of prevention practices can only be developed-over the work itself along with all of the actions and decisions used to regulate the different elements that characterize it [12]. Prevention can not be understood as a stable and limited element which is imposed to the companies, but rather as a dynamic process that is built in confrontation with the daily work. The renewal of prevention requires, necessarily, that the promotion of safety is no longer merely seen as a matter for "experts" [13] that ultimately limit interventions to the "regularities" of work activity [9]. Therefore, it is essential to recognize the role workers play in the

*E-mail: ricardo@fpce.up.pt 
companies and the importance of involving them in the design of prevention plans.

This line of thinking is also identified with interventions that view the transformation of working conditions as essential for the promotion of safety $[6$, $7,10]$. The approach underlying these interventions is framed in the scientific traditions of Work Psychology and Activity-Centered Ergonomics. These approaches are different from others, which, for addressing the issues of work, invest in training as a privileged way to transform relationships that weave among the members of the company, seeking to maintain a certain inner harmony [3]

Such epistemological choice will naturally have implications on the evaluation of the training process. The evaluation of training programs such as the one we will be presenting shifts from an external point of view to an analysis from within the training process, oriented for the specific transformations of the working conditions that it originated [5]. Consequently, the evaluation of the training is conducted in the real work [8], considering the evolution of the working conditions. The purpose of the evaluation carries on (or extends) from the training activities and the monitoring of the trainees' satisfaction to the work activities, the evolution of trainees' and trainers' knowledge and the evolution of the actual conditions for a safer everyday activity [15].

The intervention that is herein reported is framed in this concern for the actual transformation of the working conditions. Hence, it is aimed to contribute to the improvement of industrial and environmental safety in a chemical company through the development of a training process where it was possible to promote the transformation as a key element for the improvement of the work performance. This paper aims to assess what the impact of these changes was in the internal coherence of the primary work process and also between the latter and the training process itself.

\section{Method}

\subsection{Context}

The company is located in a Chemical Complex in Portugal and employs about 220 workers. The company's production process is divided into two poles of production. The first pole produces inorganic com- pounds and is composed by four chemical plants whose production processes are interdependent. The second pole is responsible for the production of organic compounds and is constituted by five chemical plants. Both poles are interdependent and are linked through conducts of steam and hydrogen.

The production is organized into three shifts (five teams) that ensure that the company works 24 hours a day. Overall, for each company's factories there are two operators per shift to ensure its functioning: a panel operator, who is responsible for controlling the automation of the production process through several displays that allow him to monitor indicators such as temperatures, pressures and concentrations, and an outside operator, responsible for the external part of the plant and performs several control operations for product quality, always in close cooperation with his plant's panel operator.

\subsection{Reasons for the intervention}

The process started with a request for an intervention designed to promote industrial and environmental safety [2]. Since the first contacts with the company's management, it was clear that the main HSW concerns were related to the prevention of industrial accidents involving hazardous chemicals (toxic, corrosive or flammable) such as leaks, spills or the release of chemicals onto the atmosphere. These industrial accidents entail strong consequences for the company and for the community, whereas an accident in the company may affect the surrounding population.

Therefore, more than the legal imperative the company has a strong social imperative to the community. In addition, safety is also a market-oriented economic and financial need, as a criterion for negotiating partnerships with potential clients.

\subsection{Participants}

115 out of the 220 company's employees were directly involved in the intervention. These elements were divided into 10 training groups over 14 months (May 2010 to June 2011). Each group had about 12 elements, representative of various ranks and functions, such as industrial operators, foremen, production coordinators and supervisors, safety technicians, different elements of technical support to production and maintenance technicians. 
Figure 1 - The logic of Matriosca participatory hands-on training

\subsection{Methodological Approach: Matriosca Model}

Theoretically and methodologically, Matriosca Model (which, in Portuguese, is an acronym for Matrix of Work and Occupational Risk Analysis for Supervisors, Managers and Support Structures) seeks to articulate the training plan in two processes: individual guided analysis of the activity of industrial operators in the workplace, and collective discussion in training groups, where the results of the individual analysis in the workplace are shared and debated. Among the trainees, in addition to industrial operators, other stakeholders, relevant to the issues under discussion, are represented. Work psychologists mediate this process.

As it has already been done elsewhere $[2,3,10,14$, 15], we will not go through all the moments and methodological options of the Matriosca Model.Our focus will be primarily on the description and evaluation of this specific intervention.

Figure 1 shows, schematically, the logic of the participatory hands-on training developed during the intervention. It is based on a cyclic movement in which training and transformation of working conditions influence each other in an intercommunicating process.

\subsubsection{First step: Getting to know the field and the real work}

The first steps of the intervention consisted of a series of activities necessary for understanding the reality of work and for the definition of the situations that would later be addressed during the process (consultation of internal documents, interviews with some stakeholders). Secondly, and for about a month, the work psychologists have analysed the activities that were essential for understanding the relevant situations. At this point, besides the activity of the industrial operators, there was also the interest of analysing activities that normally fall outside of interventions of this kind, such as the activities performed by maintenance technicians, safety technicians and production coordinators and supervisors. It was during these moments of activity analysis that the problemsituations (with implications for health and safety, quality or work organization) were collected.

These problem-situations took the form of schemes that summarized and allowed to analyze critical aspects of work, comprising the analysis of the prescribed tasks, its deviation from the real work activity, more or less naive explanations of the actions for resolution and, finally, the necessary compromises to solve the the problem at hand.

2.4.2. Second step: Training group and interchanging analysis

After the initial activity analysis, it is set in motion the cyclical movement of the training pole with the sessions in the classroom. As shown in Figure 1, the training part of the project, illustrated in the right side, consists of four phases: Collective sessions in the classroom, individual guided analysis in the workplace, collective discussion and validation in the classroom and data integration. Hence, with each of the 10 training groups, the work of analysis consisted, during two weeks, in alternating between moments of collective analysis in the classroom and moments of guided analysis on the workplace with each group member. 
After each group goes through the process described above, the results and conclusions are communicated to the "Monitoring Committee". This structure, created among the Model to function as the central axis, guarantees the essential conditions for achieving the actions and development plans designed by each group [15]. Several departments of the company are represented in this comitee. They are joined by one representative of each group (cumulatively, as the groups follow each other) and three Work Psychologists/Trainers.

This comitee and the discussion generated by it trigger and promote a transformation process which has a dialectic influence in the training process, either materially, by the introduction of new elements in the following analysis and discussions, either emotionally, by the realization among the stakeholders of the real and almost imediate impact that their actions implied. So with the Monitoring Committee in a pivotal position, it is possible to conceive another pole, the transformation of the working conditions (the left pole, figure 1). The cycle of transformation is also split into four parts: further specific analyses, intervention plans and people in charge, work transformation and sectorial monitoring meetings.

Each training-transformation cycle lasts approximately one month, one week corresponding to the specific preparation of the work in the classroom, two weeks of interchanging between classroom and workplace and one week for preparation of the meeting with the Monitoring Committee.

\subsubsection{Third step: Evaluation, Consolidation and Dis- semination}

After the completion of all the scheduled training groups, the following step was the first moment when the evaluation gained formal and shared visibility.

During the months of June and July 2011 systematic sectoral balance meetings were carried out with several departments in order to identify/validate all the actions of transformation that were performed and, in some cases, to define timings for the implementation of the improvement proposals. The data were systematically collected in a portfolio that includes all the identified problem-situations, as well as the transformation proposals that had already been implemented and also those that were lacking implementation. This follow up information has been given back to industrial operators, engineers and production supervisors, thus also constituting moments of "informal training".

There have also been conducted interviews with four stakeholders with different degrees of participation in the Model. These interviews were taped, transcribed and analyzed and the conclusions drawn formed the basis for the elaboration of a questionnaire to be presented in the consolidation and dissemination sessions scheduled for October and November 2011.

Table 1

Up-to-date status of the problem-situations by category

\begin{tabular}{|c|c|c|c|c|c|}
\hline \multirow[t]{2}{*}{ Problem situationis categories } & \multicolumn{5}{|c|}{ Status of the implementation of the problem-situations } \\
\hline & d Solve & Pending Resolution & Abandoned & $\begin{array}{l}\text { Not presented in the } \\
\text { Monitoring Committee }\end{array}$ & Total \\
\hline Working conditions & 70 & 21 & 50 & 2 & 143 \\
\hline Work Organization & 6 & 2 & 11 & 0 & 19 \\
\hline Process improvement & 4 & 2 & 9 & 1 & 16 \\
\hline $\begin{array}{l}\text { Formal vs. informal organiza- } \\
\text { tion }\end{array}$ & 1 & 1 & 2 & 1 & 5 \\
\hline Behaviors and attitudes & 3 & 2 & 5 & 0 & 10 \\
\hline Psychosocial Issues & 0 & 0 & 0 & 7 & 7 \\
\hline Total & 84 & 28 & 77 & 11 & 200 \\
\hline
\end{tabular}


Table 2

Reasons for turning down problem-situations

\begin{tabular}{|l|l|l|l|l|l|}
\hline "Abandoned" Problem-Situations \\
\hline Reason & $\begin{array}{l}\text { Equipment } \\
\text { replacement }\end{array}$ & Irrelevant Risk & Cost/Effectiveness & Incomplete Analysis & $\begin{array}{l}\text { To be analysed in } \\
\text { another context }\end{array}$ \\
\cline { 2 - 6 } & 7 & 33 & 19 & 7 & 11 \\
\hline
\end{tabular}

These sessions will be conducted with each group. Each one will last 4 hours and the main purpose is making a global balance of the results, the difficulties experienced in the intervention, lessons taken and how to maximize the impact of such intervention.

\section{Results}

The training process and its evaluation arenot stable and predefined moments, but moments that are blended with the work activity itself, which is in constant evolution and transformation. The elements outlined here allow us to get a perspective on the intercommunication between training and transformation.

So, to evaluate this intervention different kinds of data were collected: (i) categorization and up-to-date status of the different problem-situations that have been identified; (ii) Evolution of the problemsituations during the intervention; (iii) Illustrative elements of the intersection between training and transformation and (iv) Interviews with participants in the process.

\subsection{Categories and status of the problem-situations}

Table 1 shows the status and the different categories of the 200 problem-situations that were identified during the intervention. Up until now 84 situations were targeted by an intervention due to the direct action of the training groups in close collaboration with the management and the different departments that support production. Most of them were related to "working conditions".

After the presentation of the problem-situations in the Monitoring Committee by the Work Psychologists / group representatives, 77 situations were considered "abandoned." The reasons for this categorization are diverse. In many cases it was considered that these situations involve risks that are irrelevant to the operator / environment or, on the other hand, the cost-effectiveness associated to an intervention in that situation doesn't justify it. Table 2 shows the different reasons why the problems were "abandoned".

\subsection{Evolution of the identified problem-situation}

The majority of problem-situations were object of intervention throughout the training process due to the action of the training groups (whom defined commitments and drew suggestions for improvement).

Once the Monitoring Committee had evaluated each problem-situation, one person was held responsible for the implementation of the suggestions and a team was set to monitor the status of the implementation. Figure 2 shows the evolution of the overall number of problem-situations that were identified and the number of these that have already been object of an intervention, having as a time reference the Monitoring Committee meetings

With the recurring analysis of work activities by the Work Psychologists and the development of training groups, the absolute number of problemsituations to be presented in the Monitoring Committee increased as the months went by.

The movement of the work transformation pole, strongly driven by the decision-making power of this Committee, starts in the third meeting where we can see the first two situations that were object of an intervention.

An analysis of the implementation of the actions outlined in the Monitoring Committee shows that there is an obvious connection between them and the Monitoring Comittee meetings.

The monitoring of the implementation status of the actions outlined for each problem situation was performed by the team of psychologists through sectoral balance meetings with the departments involved. 


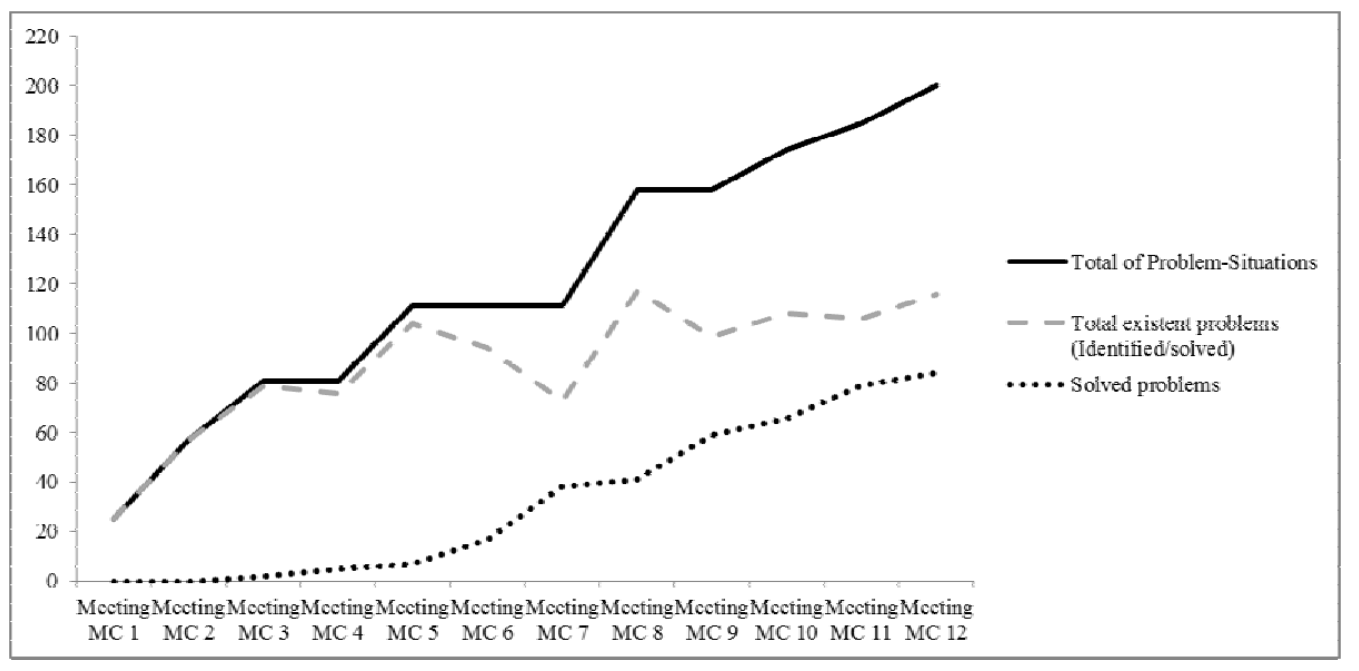

Figure 2. Global evolution of Problem-Situations

\subsection{Intersection between training and transformation}

The activity analysis made over the past 15 months allowed the identification of 200 problem-situations. One of those was selected as an example to describe in detail.

This choice had to do with the constraints associated with a scientific publication, that makes it impossible to describe in detail each of the problemsituations, but also and mainly due to its represesentativeness of the intersection of the secondary process (training) over the primary process (work).

The chosen problem-situation is, then, related with the excessive amount of alarms on control panels during the plants' start-up and was reported by panel operators.

The panel operators' function involves the control of the plants through a Distributed Control System that monitors digitally all the areas of the facilities that they must oversee (each operator can control up to 5 displays). This system emits "alarms" that allow operators to control in advance, several indicators of the process, avoiding safety, production and quality problems.

Whenever a plant stops (which can happen for several reasons such as voltage drops or noncompliance of some indicators), it is necessary to start it up again. But, during this process, the control system loses some of its features until the production process is stabilized, which can last up to 6 hours. In this period, the panel operator only has an analog control of the process, receiving multiple alarms from the control system that communicates the deviation among some of the indicators in relation to the production standard (about 450 alarms during start-up moments). But until the moment when the production process stabilizes - the time when the system starts to control the process digitally - there's a very demanding period of time that requires great attention from the panel operators that have to analyse manually the several alarms generated.

During the work activity analysis and the preparation of training groups, the situation regarding the excessive number of alarms generated when the factories were starting up was identified by operators as the main constraint on their activities. They were also the only ones to recognize it as a problem. This problem situation was discussed and validated collectively in classroom context during training groups. Later, during the meetings of the Monitoring Committee, the managers and decision-making structures of the company analyzed this situation. In order to implement the improvement proposals outlined by the committee it was created a multidisciplinary team aimed at establishing a new categorization of the control system alarms and the setting of priorities and predominance of the issued alarms. This work implied a detailed analysis of each alarm in order to eliminate any redundant alarms and this without affecting (actually, benefiting) the work process. In some cases, there was a decrease around $50 \%$ of the 
number of alarms generated in both start-up situations and in situations of stable production. In addition to the significant reduction in the number of alarms generated, it was still possible to define that, contrary to what had happened earlier, the most important alarms started to appear in a prominent position in the display, making it easier for the panel operators to decide.

This work of alarms reorganization was only developed in one production pole and is currently being implemented in the second.

\subsection{Participants in direct speech}

To assess the subjective opinion of participants, four stakeholders who participated in Matriosca Model were interviewed. This data was later on used as a guide for the development of an evaluation questionnaire to be applied in the final phase of the project (see point 2.3.3).

One subject was, due to the position he holds in the company (Director of Human Resources), one of those responsible for monitoring the intervention in what concerns the organization and negotiation of the request. The remaining three subjects were part of supporting structures of the company and participated in Matriosca Model's training groups. It was not possible to interview any element of production due to lack of availability at the time when these interviews were conducted.

The interviews were semi-structured and the subjects were asked to reflect upon their participation in the Matriosca Model during the various phases of the intervention (as shown in Figure 1).

A first analysis (necessarily global and generic due to space limitations) to the contents of the interviews highlighted the following:

- All subjects refered as a positive aspect of Matriosca Model the fact that it adapted its methodolgy to the needs of the context and underlined the importance of listening to the workers. Moreover, all of the interviewees who participated in the collective classroom sessions of the intervention indicated an open climate for problem discussion without fear of reprisals. One of the subjects refered that going to the workplace allows a deeper analysis of problem-situations;

- Some subjects reported, however, some difficulties encountered in the Monitoring Committee, particularly regarding the lack of involvement of some managers, the lack of follow-up to some problem-situations and the limited budget for the execution of some of the outlined actions.

A detailed analysis of the content of the interviews, the way how, from there, the questionnaire to be used in the next phase was made, as well as the results of its implementation, when available, will be the subject of another publication.

\section{Discussion}

It is undeniable that, from the analysis of the data presented above, this intervention originated a process of transformation, based upon the 200 problemsituations raised (of which 84 have been resolved) (see point 3.1).

It can be said that the emergence of these "problems" is inevitable if we keep searching for a greater coherence in the primary process of actions and decisions through the secondary process, which is training. If one perceives training as a process that finds its support in the work reality allows to unveil a whole range of situations that otherwise would be hidden (and would always be hidden if, in this case, training had been seen as the superficial, traditional, cumulative and arithmetic transmission of knowledge).

The raising and discussion of concrete problems of work in an open multidisciplinary context also allows the construction of a common framework among the various stakeholders [11] and a consequential dialectic enrichment of their perspectives.

This enrichment of perspectives leads to the enrichment of the transformation process that will thus be more sustained in the activity where it was originated. Also, the transformation process and the common framework that is built also help the training process, which, as it is sustained in the context, should not ignore the "new" reality that is being created. The analysis of the evolution of the growing number of problem-situations arising throughout the process (see 3.2) allows us to see the influence of the transformation process in the training process itself.

For instance, by turning the excessive number of alarms mentioned by the panel operators into common knowledge (see Section 3.3) a new awareness of the panel operators' reality arised and, consequently, solutions for the improvement of the working conditions were discussed.

Finally, the involvement of some stakeholders in the last phase of the intervention - interviews (see 3.4) - helped to enrich the process of evaluation of 
Matriosca Model. Understanding how the stakeholders perceive the impact of the intervention and the positive and negative aspects of each phase will complement the quantitative results discussed in 3.1 , 3.2 and 3.3 with a more qualitative approach to the Model, paving the way to a deeper and richer evaluation that will certainly go on in the near future

\section{References}

[1] D. Cru, La parole est à vous. Prévention et formes du dialogue social, Revue de médecine du travail 27 (2000), 119-126.

[2] S. Duarte, R. Pinto and R. Vasconcelos, Gestão da formação em segurança numa empresa industrial química: debates entre a rigidez formal e a eficácia potencial a partir de um estudo de caso, in P. Arezes, J. Baptista, M. Barroso, P. Carneiro, P. Cordeiro, N. Costa, R. Melo, A. Miguel and G. Perestrelo, eds., Poceedings of SHO 2011 - International Symposium on Occupational Safety and Hygiene, 2011 Feb 10-11, Guimarães, Portugal. Guimarães: Sociedade Portuguesa de Segurança e Higiene Ocupacionais, 2011, pp.255-260.

[3] M. Lacomblez and R. Vasconcelos, Análise ergonómica da actividade, formação e transformação do trabalho: opções para um desenvolvimento durável, Laboreal [internet] (2009), [cited 2011 Aug 20], 5(1), 53-60. Available from: http://laboreal.up.pt/revista/artigo.php?id=37t45nSU54711242 83994283411.

[4] B. Maggi, Analisi e progettazioni del lavoro per la tutela della salute. L'orientamento innovativo del D.LGS 626/94, Sociologia del Diritto 2 (1996), 5-39.

[5] B. Maggi, Do agir organizacional: Um ponto de vista sobre o trabalho, o bem-estar, a aprendizagem [L. Sznelwar, trans]. Edgard Bucher, São Paulo 2006.

[6] A. Re, Aprendre des erreurs, apprendre du quotidian: deux approaches actuelles pour une analyse collective de l'activité, Education Permanente 166 (2006), 49-57.

[7] A. Re, S. Montagna and E. Ferrari, Improving risk management in complex systems: from reliability to collective competence. Paper presented at the $16^{\text {th }}$ World Congress on Ergonomics, 2006, Jul 10-14, Maastricht, the Netherlands.
[8] M. Santos, T. Vicente, A. Monteiro and M. Lacomblez, What is not assessed in continuous training in companies? Two case studies in Portugal, Paper presented at the $17^{\text {th }}$ World Congress in Ergonomics, 2009, Aug 9-14, Beijing, China.

[9] Y. Schwartz, R. Adriano and F. Abderrahmane, Revisitar a actividade humana para colocar questões do desenvolvimento: projecto de uma sinergia franco-lusófona, Laboreal [internet] (2008), [cited 2011 Aug 20] 4(1) 10-22. Available from: http://laboreal.up.pt/revista/artigo.php?id=48u56oTV6582235 394::8253872.

[10]R. Vasconcelos, O papel do psicólogo do trabalho e a tripolidade dinâmica dos processos de transformação: contributo para a promoção da segurança e saúde no trabalho, Ph. D. Dissertation, Faculdade de Psicologia e de Ciências da Educação, Universidade do Porto, 20008.

[11]R. Vasconcelos and M. Lacomblez, Análise guiada do trabalho e desenvolvimento de competências profissionais: Contributos reflexões e desafios, Cadernos de Consulta Psicológica 17/18 (2002), 295-304.

[12]R. Vasconcelos and M. Lacomblez, Entre a auto-análise do trabalho e o trabalho de auto-análise: desenvolvimento para a psicologia do trabalho a partir da promoção da segurança e saúde no trabalho, in: Labirintos do trabalho: interrogações e olhares sobre o trabalho vivo, M. Figueiredo, M. Athayde, J. Brito and D. Alvarez, ed., DP\&A Editor, Rio de Janeiro, 2004, pp. 161-187.

[13]R. Vasconcelos and M. Lacomblez, Guided Work Analysis as a structure upon which new prevention models should be constructed. Paper presented at: $3^{\text {rd }}$ International Congress on Occupational Risk Prevention, 2004, Jun. 2-4, Santiago de Compostela, Spain.

[14] R. Vasconcelos, S. Duarte and V. Moreira, Projecto Matriosca: Análise do Trabalho, formação e acção participativa para a prevenção de acidentes, in P. Arezes, J. Baptista, M. Barroso, P. Carneiro, P. Cordeiro, N. Costa, R. Melo, A. Miguel and G. Perestrelo, eds., Poceedings of SHO 2010 - International Symposium on Occupational Safety and Hygiene, 2010 Feb 10-11, Guimarães, Portugal. Guimarães: Sociedade Portuguesa de Segurança e Higiene Ocupacionais, 2010, pp.542-546

[15]R. Vasconcelos, D. Silva and P. Fortuna, A transformação das condições de trabalho enquanto critério para a avaliação da formação em segurança: reflexões e desafios a partir de um estudo de caso, in P. Arezes, J. Baptista, M. Barroso, P. Carneiro, P. Cordeiro, N. Costa, R. Melo, A. Miguel and G. Perestrelo, eds., Poceedings of SHO 2011 - International Symposium on Occupational Safety and Hygiene, 2011 Feb 10-11, Guimarães, Portugal. Guimarães: Sociedade Portuguesa de Segurança e Higiene Ocupacionais, 2011, pp.255-260. 